\title{
Almost True: (Non)Fictionality in Contemporary US-American Migration Narratives
}

\begin{abstract}
Dieser Beitrag verknüpft (US-amerikanische) Diskurse zur USamerikanischen Migrationsliteratur mit (US-amerikanischen) gegenwärtigen Diskursen zu Faktizität und Fiktionalität. Der Angelpunkt dieser Verknüpfung sind US-spezifische, kulturhistorisch zentrale Mythen (Barthes) bzw. „deep stories“ (Hochschild) wie der „American Dream“ und die „Nation of Immigrants“. Die Grundannahme für diese Verknüpfung ist, dass sowohl in der Rezeption von Migrationsliteratur als auch von zentralen Aussagen politischer Akteure und Institutionen die Unterscheidung zwischen Fiktion und Nicht-Fiktion, Fakt und Kontra-Fakt durch diese mythischen Narrative aufgehoben wird. Binäre Erklärungsmuster für dieses Phänomen verfehlen dementsprechend dessen wesentlichen Aspekt.
\end{abstract}

\section{Based on True Events: Introduction}

Here is a curious phenomenon: in reviewing, analyzing and discussing contemporary US-American immigrant fictions, many - in fact, almost all - critics (most of them US-American) in one way or another refer to the author's biography. The reference may be tangential or central to the argument, it may explicitly employ the adjective 'autobiographical' or not, but where it is made, it is invariably made as a rhetorical gesture of authentication. It is supposed to indicate that there is an inherent connection between the narrative and the author's life and personal experiences, and that therefore the narrative is somehow more 'truthful', 'credible', or, in other words, 'authentic'. This connection is rarely, if ever, specified in detail. Usually, critics point to some general parallels between the narrative and its protagonists and the author's life in terms of target / source country, migrational experience, and / or family constellation. In other words, the term 'autobiographical' is not used as the adjective of the noun autobiography, but rather as a shortcut for 'contains some facts and / or events similar to

Rüdiger Heinze, Technische Universität Braunschweig, r.heinze@tu-braunschweig.de ¿ Open Access. (C) 2021 Rüdiger Heinze, publiziert von De Gruyter. (cc) BY Dieses Werk ist lizenziert unter der Creative Commons Attribution 4.0 International Lizenz.

https://doi.org/10.1515/9783110693065-015 
those of the author's life'. In their urge to establish what we might call 'autobiographicality', critics sometimes go so far as to completely ignore blatantly divergent aspects such as gender, age, decade, or socioeconomic context.

As if to warn against such facile appropriation by critics, the novels and / or short stories in question occasionally even contain forewords by, or interviews with, the authors emphasizing that their narrative is fictional and that while certainly personal experiences inevitably make their way into one's writing, and while there may be some general similarities (say, number of siblings, country of origin, migrational route), they as authors are not to be trusted and cannot themselves reliably remember what really happened and what did not - and that apart from all this, the distinction between fictional and nonfictional should not matter for the relevance of the story. Nevertheless, contemporary writers particularly popular among critics for such 'autobiographical' reception are, for example, Jhumpa Lahiri, Julia Alvarez, Junot Díaz, Ana Castillo, Amy Tan, Angie Cruz, and many more. Indeed, regarding some writers (Lahiri or Alvarez, for example), it is hard to find a review or a critical essay that does not employ this kind of authentication. Even the well-known novelist Anne Tyler, an almost prototypical 'WASP', is frequently awarded (in various reviews) the credit of having 'authentic' access to the Iranian American immigrant experience in her novel Digging to America because she was married to an Iranian immigrant.

For example, in her otherwise insightful and detailed essay on what she calls "pseudo-memory" and trauma (in How the García Girls Lost Their Accents and in the follow-up novel ;Yo!), Jessica Cantiello does not consistently distinguish between fiction and pseudo-memory (which is defined as invented memory), nor does she distinguish between the fictionality of the novel per se and the fictionality of the pseudo-memory within the novel, although their indexical and logical relation to the actual world is substantially different. Cantiello even explicitly writes that "storytelling is a complicated confluence of truth, lies, and memory, and memory is not always to be trusted" $(2011,85)$, that "one cannot assume that any version of the story is in fact the best, the most authentic, or the most real" $(2011,86)$, and that the novels are a "conglomeration of pseudo-memories, as the characters' memories and stories from the first book intermingle and contradict each other" $(2011,92)$ and thus contain "many different voices" $(2011,93)$ and a "multiplicity of representations" $(2011,94)$. In short, it would seem that the only logical conclusion is that there is no steady ground on which to base the claim that the two novels are autobiographical. Yet the baseline argument for her essay is that Alvarez's two novels are "autobiographical” and that they feature an "alter ego named Yolanda García, whose 
stories draw from Alvarez's own life” (2011, 83). Like many other critics, she refers to Alvarez's abundant nonfiction publications (essays and interviews), in which the latter repeatedly states that she has drawn material for her novels from her own life and family, in order to substantiate her claim. However, in those same interviews and essays, Alvarez also repeatedly admonishes that her memories are already "just stories" and are "recast" to fit the demands of the fiction, and that she has altered, added and subtracted so much that she, herself, cannot really tell what is what, and does not see the need to.

Another example for this kind of 'illegitimate authentication' is the reception of Jhumpa Lahiri's fiction. In a recent New York Times review of Jhumpa Lahiri's latest book, the collection of short stories Unaccustomed Earth, the author writes that the underlying theme of all stories is "the fact that America is still a place where the rest of the world comes to reinvent itself" and that "the place to which you feel the strongest attachment isn't necessarily the country you're tied to by blood or birth: it's the place that allows you to become yourself. This place [...] may not lie on any map" (Schillinger 2008, n. p.). This assessment is accompanied by a reference to the biography of Lahiri, who was born in London to Bengali immigrants and raised in Rhode Island, and would thus qualify as an example of the children of immigrants frequently portrayed in her stories. The biographical reference is used to authenticate the author's privileged access to the experience of children of immigrants. The fact that there are significant differences between Lahiri and her protagonists (in terms of gender, class, historical and cultural contexts) is hardly ever afforded any attention. All in all, the review pays little attention to the stories as fictional narratives but rather treats them as if they were slightly embellished social reports based on Lahiri's own life and experiences; this pattern recurs in various critical essays.

To some degree, this phenomenon is not entirely surprising, nor is it new. Many early US-American immigration narratives are autobiographies, memoirs, diaries, or compiled letters. They are life writings about becoming American, assimilation, and identity and follow the formal traditions of earlier canonical US-American autobiographies. These narratives about marked (i.e. minority) cultural practices have a long tradition of being read as slightly embellished, but basically 'authentic' / 'true' / nonfictional social reports or ethnographies (more on this below). Accordingly, their authors often were and still are regarded as informants about the life and cultural practices of 'their' cultural formation. Contemporary reception and criticism of narratives about marked cultural practices, including those signposted as fictional, obviously still carry vestiges of this ethnographic tradition: the texts are treated as 'authentic' and 
thereby implicitly nonfictional representations of the 'cultural identity' of a particular group and / or the author.

Even if we can explain the anamnesis of this phenomenon, this does not explain why it persists and what it signifies today. Why is it still so widespread? Why is it hardly afforded attention in critical literature? Why is it focused almost exclusively on narratives about marked cultural practices and much less on, for example, fictional narratives about crime or destitution? Most importantly, what is its relevance in the contemporary US-American cultural context?

It would be easy and tempting to see this purely as a matter of identity politics. Of course it is, in part. These are narratives about migration, identity, and culture(s). In the US-American context, it would be hard to imagine that their reception could not invoke identity politics. Feuilleton writers and commentators on both sides of the Atlantic outbid each other in pointing out that and how contemporary US-American culture is all about identity politics. ${ }^{1}$ In fact, this claim itself has become an almost unquestioned narrative and myth. And while identity politics certainly play a role in explaining this authentication of fictional migration narratives as 'almost nonfictional', they are not the whole story.'

More specifically, I argue that there are several interconnected concepts and discourses at play here, namely authenticity, cultural identity, and fictionality. Without taking them all into account, we cannot understand the obvious penchant by reviewers and critics to authenticate migration narratives as 'au-

1 Ironically, the various US-American political groups on the right have adopted the essentialist logic of identity politics for their purposes. It is fitting, then, that many right-wing political movements are dubbed, or dub themselves, as 'identitarian', both in the USA and abroad. Interestingly, in an interview with Robert Kuttner, Steve Bannon explicitly comments on identity politics: "The Democrats, the longer they talk about identity politics, I got 'em. I want them to talk about racism every day. If the left is focused on race and identity, and we go with economic nationalism, we can crush the Democrats" (2017, n. p.).

I am aware that the binary ascription of 'left' and 'right' to political movements is somewhat reductive. The spectrum of political movements in the USA is actually more diverse than it is made out to be in much political commentary. Even within 'the right' and 'the left' there is quite a lot of diversity.

2 As Nancy Isenberg points out in her recent monograph on 'white trash' in the USA (2016), American politics has been about identity politics for a long time, in various different forms and guises. Also, in light of the immigrant history of the USA and the concurrent debates, it is naïve and counterfactual to think that there was ever a time when a vast majority of (US-)Americans wholeheartedly embraced the notion that they are a pluralistic society / culture containing many different 'cultures' on equal footing, or that this, if it was the case, would be a good thing (2018). Samuel Huntington's Who Are We (2004) is just one prominent example of what Sämi Ludwig terms 'thin pluralism' (2003). 
thentic' / autobiographical (in the sense explained above) and the wider cultural significance of that penchant. In fact, I will try to show that this phenomenon has wider cultural significance in that it is actually indicative of a much more general and deep going cultural phenomenon - a phenomenon which in turn underlies recent developments in US-American politics and which has variously been labeled 'post-truth' or 'post-factuality'. The terms refer to the puzzling fact that the outright and evidential falsehood and contra-factuality of numerous claims and statements, often part of entire made-up conspirative stories such as underlying the 'birther-movement', made in various different public discourses (mostly in the political arena, mostly by prominent political personnel) does not appear to have any relevance at all regarding their credibility for a significant section of the receiving audience. On the contrary, such communicative behavior and the attending invented stories appear to be a sign of authenticity and reliability for their 'believers', and not mendacity and inconsistence, as could be expected. Attempts to explain this phenomenon of 'post-factual' communication and narration within the binary logic of true / false or factual / non-factual are doomed to fail exactly because this communicative strategy purposely eschews and circumvents this binary logic and therefore cannot be explained by it. The phenomenon becomes quite clear, however, once one realizes that these claims and stories operate not on the level of factual / non-factual but rather 'authentic', a kind of 'third term' that supersedes factuality by working with, and appealing to, 'felt' truth. In other words, these invented claims and stories either themselves are or construct mythic narratives (in the Barthesian sense) or appeal to widespread cultural myths, resonating with what people feel is true, regardless of facts. This phenomenon, somewhat ironically and paradoxically, connects, as I argue, these invented narratives to fictional narratives about cultural identity.

\section{Cross My Heart and Hope to Die: Authenticity, Cultural Identity \& Fictionality}

Generally, it seems that certain experiential areas seem to make special demands on their representation and fictionalization. Again and again, memoirs, autobiographies, and other allegedly nonfictional texts about certain themes and experiences such as abuse, discrimination or, most drastically, genocidal persecution that turn out to be invented kindle severe excoriation; the literary scandals are legend. Texts that break the autobiographical pact between author 
and reader - which many modern and postmodern historiographic metafictional narratives have done with relish in order to point at the narrativity (and thus implied partial fictitiousness) of history - meet with criticism whenever they do not at least announce their 'mendacity'. Narrative theorists that conflate the difference between fictional and nonfictional - correctly pointing out that there is no failsafe single way to determine the difference and that they share narrative strategies - should, according to Sidonie Smith and Julia Watson, at least acknowledge the problems of this conflation (2008).

Even fictional texts about special experiences are treated with suspicion based on the assumption that such experiences cannot, should not, or must not be fictionalized. When they are, their fictionalization is usually expected to be especially scrupulous and exacting in its depiction of these experiences, though it is seldom clarified just what scrupulous and exacting may mean in this context. Literary texts about cultural practices, among them immigrant fictions, often meet with similar demands, which I would attribute to the ideological baggage of ideas of cultural identity and difference they are assumed to carry. As Werner Sollors points out, "ethnic writers operated under a system that has been called 'compulsive representation,' for they were often read as informants about the collectivities they were believed to embody" (2002, 390), so that "readers have overemphasized and exaggerated the (frequently exoticized) ethnic particularity of the works" (1986, 11). Put the other way around: "Are the respective texts duty-bound to be representational, some prescribed version of the community from which they arise? [...] Does a demographic minority always write minority literature?" (Lee 2012, 114)

That this is still topical can be seen in a recent fictional meta-commentary by the author Nam Le. The short story opening his collection The Boat is an ironic exemplification of this kind of reduction. An author struggling with a writing assignment and writer's block is given the advice to exploit his (respectively his father's) Vietnamese background and write 'hot' ethnic literature. The title of the story, "Love and Honor and Pity and Pride and Compassion and Sacrifice”, pits this marketing truism against Faulkner's advice to write about grand and universal themes rather than 'special interest' issues, which in this case would be ethnicity and multiculturalism. Fittingly, the protagonist decides to write a story about his father's involvement in the Vietnam War that never gets read except by his father, who then destroys it. While the story in the story is never published, the story with the above title evidently was published, turning it into a succinct exemplification of the paradoxes and problems implicit both in labels such as ethnic or multicultural literature on the one hand and in ideas about universal human themes on the other; most of the remaining stories in 
the collection are about exactly the varied themes the author in the opening story really wants to write about, but is discouraged from writing with reference to his rich biographical 'source material'. To boost, in a rush to claim the successful young author with a Vietnamese-Australian background (who has no other claim to being an US-American writer either by birth or deliberation than having attended the Iowa Writer's Workshop), he was hailed in various reviews of US publishing organs as a promising young American writer, and his stories have appeared in collections such as Best New American Voices.

The interconnected assumptions behind this are that migrational experiences and the cultural practices of immigrant groups are special and revealing of a person's and a group's 'cultural identity'; that all such texts should also be especially 'authentic' in the representation of these experiences; and that even the leeway usually granted to fictional texts is overridden or at least restricted by the demand to 'authentically' represent these special experiences and identities. The conceptually problematic notion of cultural identity and representation underpinning this chain of assumptions is here compounded by the conceptual and definitional challenges of authenticity and fictionality. While fictionality is at least a narratologically differentiated and problematized concept, the renewed, proliferating and multidisciplinary usage of authenticity is primarily characterized by a definitional lacuna or paradigmatic substitution with synonyms such as sincerity, honesty, purity, or even 'truthiness'.

The problem with authenticity is that it is an essentially empty category that is so flexible and vague that it is easily adapted for pretty much any purpose, which explains its enormous popularity. It has its most influential advocacy in existential philosophy, where it is used to characterize, for example, a life or an artwork that is the 'true', 'creative' and 'original' expression of an 'essence'; however, even here, it is usually defined negatively against the 'inauthentic', for example by Charles Taylor in his influential The Ethics of Authenticity (1991) or, much earlier, by Lionel Trilling in his equally influential Sincerity and $A u$ thenticity (1972). Accordingly, modernist discourses of individual autonomy and uniqueness place the authentic individual against the ideologically and socially tranquilized - and thus 'dishonest' - individual that leads a life prefigured and dominated by traditional structures (Haselstein et al. 2010, 10); discourses of avant-garde art (or performance art, or postmodern theater) often define authentic over and against tradition, imitation, and copy (Fischer-Lichte and Pflug 2000, 3); and discourses of literary texts and traditions about cultural identity 
usually posit a minority, non-hegemonic authentic literary expression over and against a perceived homogenizing, oppressive mainstream culture. ${ }^{3}$

Unsurprisingly, deconstruction, poststructuralism, and postmodernism have trenchantly taken apart these binaries (or, in the terminology of Derrida, violent hierarchies); more surprisingly, as a number of recent conferences and publications demonstrate (and criticize), authenticity has re-entered various contemporary discourses, most often in the guise of 'the return of the real'. Appropriately, Haselstein et al. have titled their collection The Pathos of Authenticity. In actuality, the term has come to be a soft version of truthfulness to whatever. In the introduction to their collection of essays Funktionen von Wirklichkeit (2011), Wolfgang Funk and Lucia Krämer describe the basic dilemma:

Ein ästhetisches wie ontologisches Paradox steht gleich einem Kafka'schen Torwächter vor jeder theoretischen Auseinandersetzung mit dem Phänomen 'Authentizität'. Dramatisch verkürzt könnte man dieses Paradox auf die Formel bringen, dass sich Authentizität als ästhetische, epistemologische und ethische Kategorie per definitionem jeglicher Form von eindeutiger Repräsentation notwendigerweise entzieht, oder anders ausgedrückt, dass sich ,echte' Authentizität sowohl einer Person wie eines Objekts oder Kunstwerks nicht erklären, sondern höchstens (unzureichend) beschreiben lässt. Diese Annahme begründet sich darin, dass als bestimmendes Merkmal der Authentizität - zumindest im zeitgenössischen Verständnis - der unmittelbare und unvermittelte Ausdruck eines wie auch immer gearteten, unveräußerlichen (im strikt wörtlichen Sinn) Wesensgehalt [...] angenommen wird, ein Kerninneres, das seine ästhetische wie ethische Überzeugungskraft eben daraus bezieht, dass es sich weder explizieren noch instrumentalisieren lässt. $(2011,8)$

In other words, authenticity is not only semantically dependent on its discursive context (in which its meaning / use may differ significantly) but essentially 'empty' because once it is represented, once the ascription of anything as 'authentic' is explicated and elaborated, the authentic ceases to be authentic just because the logic of the term demands that it cannot be re-presented, repeated, imitated, etc. Most of the time, authenticity is one part of the binary 'authentic / inauthentic' that, depending on the context and discipline, comes in variations such as 'original / imitation', 'sincere / ideological', 'truthful / distorting', 'subversive / hegemonic', or 'minority / majority'.

It should be obvious just how problematic these binaries are with regard to literary texts about migrational experiences and cultural practices. There is no definitive authority to determine just what counts as authentic and what does

3 For an overview of various uses of authenticity in different discourses, see Newman and Smith's essay on "Kinds of Authenticity" (2016). 
not; more importantly, this kind of authenticity implies a static and homogeneous notion of culture and cultural identity behind cultural practices, and thus a notion of literary texts as mainly mimetic and static representations of 'real' and 'true' experiences and a 'real' or 'true' 'identity'. If we treat literary texts about cultural practices as a kind of social report about a special real-world experience, the status of such texts as fictional constructions is of secondary importance. No wonder, then, that 'authenticity' is often found in the context of the discourses I am talking about: if autobiographical is a soft version of nonfictional, and if nonfictional is truthful and therefore authentic, then autobiographical equals authentic.

Perhaps the best known examples of this kind of logic are the notorious debates between Frank Chin and Maxine Hong Kingston, and between Leslie Marmon Silko and Louise Erdrich. Both debates are symptomatic of the tensions between postmodernism and multiculturalism and of the question how 'best' to 'authentically' represent cultural identity, if that is deemed possible at all. In her essay on multiculturalism in the contemporary American novel, Martha Cutter explains the problem: what agency can a fragmented self have? Is it not just at the time when white postmodern writers announce the death of character, reality, and history that these matter for multiethnic writers beginning to be heard, read, and represented? (2012, 111) “[I]n many works of contemporary multiethnic literature, it is precisely questions of history and historical reality that are at stake: who is allowed to write history? What voices are elided from this writing of history? And, most importantly, what points of view must be reinstated and in what ways?" (2012, 110) Contemporary literary practice has long moved beyond this opposition; many postmodern 'Anglo'-American writers incorporate questions of race and ethnicity, and many multiethnic writers use postmodern aesthetics (2012, 124). But many critical debates and reviews still cling to the question of 'appropriate' representation and authenticity, often cloaked in the reference to alleged 'autobiographical' (read: authenticating / legitimating) elements in fictional narratives.

The issue is compounded by the specific history of the USA, in which, from its inception, narratives of national identity, immigration, and cultural identity have intersected in complex and often contradictory ways, occasionally overshadowing or even supplanting other narratives, most importantly class. The current phenomenon of post-factual narration cannot be understood without this historical context. As a nation founded in opposition by an already diverse group of immigrants / colonials, on a new continent, with a new landscape and ecosphere, with a new political organization, new laws, social life, institutions, and infrastructure, which then became an ever-changing (demographically, but 
also geographically) nation of immigrants, the USA has from the very beginning intensely debated the question of its national and cultural identity; much more so, and much more explicitly so, than most other nations. That debate has never stopped. Since immigration is one of the key components and myths of the USA, past and present, immigration per se is necessarily at the heart of any debate about the nation's identity, thereby unavoidably turning US-American immigrant literature into one central arena for that debate. As a result, immigrant fiction is never 'just' about the immigrant experience of a particular person or group; it is always, implicitly or explicitly, about the alleged cultural identity of the USA, or, in other words, about 'becoming American'. This is one reason why so many immigrant fictions are Bildungsromane or coming-of-age narratives, almost regardless of the protagonist's biological age.

However, this presents us with another problem. 'Culture' and 'cultural identity', despite the "hefty workout" (Appiah 2005, 114) these terms have been getting, are almost impossible to define. Often enough, 'culture' serves merely as an umbrella term either for all human activity ('an entire way of life') of a given community, for the sum of its artistic productions, or for those practices left once political, economic or social ones have been subtracted. In discussions of 'mainstream' culture, immigration, integration, race, and ethnicity, it is often accompanied by some metaphorical correlative equally indefinable and overand underdetermined, such as melting pot, mosaic, pizza pie, or salad bowl. At the worst, "culture and even religion can become essentialized to the point that they can serve as a functional equivalent of biological racism - culture, put another way, can do the work of race, when peoples or ways of life are seen as unchangeable as pigmentation" (Foner 2005, 217). In the context of a critique of hybridity, Floya Anthias argues that belonging and personal and collective identity "do not depend solely on cultural practices or beliefs" $(2001,622)$, that the notion of culture as "a core element of identity and belonging" (2001, 620) eschews various other factors such as gender and class, and that "cultural resources are only one of a set of resources used by ethnic groups" (2001, 629). In their monograph on the contemporary US-American novel, Andrew Dix, Brian Jarvis, and Paul Jenner point out that in the "wake of many forms of identity politics that have lately contested historical dominance in the US by older white males, the contemporary American novel has sometimes been understood less as a unified literary field than as a loose assemblage of multiple categories" $(2011,17)$.

However, they continue, "[v]ital though these categories have proved in helping to redress entrenched social injustices, they have nevertheless incurred costs, not the least of which is their availability for dubious commercial exploi- 
tation. This subdividing of novelistic kinds also carries the risk of further estranging one demographic fragment of the US from another" $(2011,17)$. The often perceived cultural / ethnic / racial fragmentation of the USA, then, has a long history and does not come out of nowhere.

In addition, as Walter Benn Michaels cautions, focusing exclusively on identity and difference comes at another price:

\begin{abstract}
Questions about what it means to be yellow or what it means to be American are questions about who we are rather than about how much (or little) we own, and while such questions have always played a significant role in American literature, they have [...] come to play an absolutely central role both in the literature and the literary criticism of the last thirty years. $(2011,1017)$
\end{abstract}

This, however, is a problem because social and economic injustice have taken a back seat when in actuality, issues of race and economics are intricately connected, as intersectional theory has convincingly shown. In his book The Trouble With Diversity, he claims that the USA have learned to love difference and that "[i]nstead of trying to treat people as if their race didn't matter, we would not only recognize but celebrate racial identity. [...] [W]e love race - we love identity - because we don't love class” (2006, 5-6). He continues:

A world where some of us don't have enough money is a world where the differences between us present a problem: the need to get rid of inequality or to justify it. A world where some of us are black and some of us are white - or biracial or Native American or transgendered - is a world where the differences between us present a solution: appreciating our diversity. $(2006,6)$

In fact, he argues, "the focus on identity functions not just to distract people from the increase in inequality but to legitimate it” $(2011,1027)$.

On the one hand, then, questions of cultural difference and cultural identity are profoundly irrelevant, as is the whole debate over assimilation or the refusal to assimilate; on the other hand, they are profoundly attractive, since they give us a picture not only of Asian Americans but of the social structure of the United States that, if it is deeply misleading, is also deeply gratifying [...]. (2011, 1023)

It is gratifying because an economic issue is represented as a cultural one, which is much easier to contain; after all, it is what makes America, America (2011, 1023). The myth of the USA as a nation of immigrants and cultural diversity (a myth often accompanied by the - contrafactual - myth that this diversity has always been welcomed and celebrated) has, in other words, made it difficult to address issues of social and economic injustice and inequality - exactly at a time when such inequality and injustice have increased, the recent economic 
boom notwithstanding. Whenever such issues are addressed, they are, somewhat unsurprisingly, cloaked in the mantle of national and cultural identity. ${ }^{4}$

The recent study on the US-American Right by sociologist Arlie Russell Hochschild (2016) elucidates this conjunction of authenticity, identity, economics, and fictionality. Taking numerous extensive interviews with citizens who self-identify as 'right' as her corpus, she 'extracted' and then abstracted a 'deep story' about what is going on in the USA today (similar to Propp's morphology of the folk tale), which she then 'fed back' to her interview partners in a feedback loop to see whether they agreed with it; all of them did, with some minor revisions. That deep story, it turns out, is about the amorphous 'American Dream' and its failure. What is crucial for my argument is not only the actual content of the story - it is mostly about economic disillusionment and frustration, and actually a vindication of Bannon's strategy of focusing on economics and nationalism - but also its key aspect: “A deep story is a feels-as-if story it's the story feelings tell, in the language of symbols. It removes judgment. It removes fact. It tells us how things feel” (Hochschild 2016, 135). It is important to note that, as she points out, we all have a deep story. Even though the actual term is not used, we could just as well say that a deep story is a story that feels 'authentic' without much regard for factuality - a deep story is, in fact, a myth. It becomes more important that certain narratives present what is considered either by the majority or by other members of the respective group - an 'authentic' rendering of a special experience. This is, clearly, quite similar to the conjunction of authenticity and identity in the reception of immigrant fictions: it is characterized by the feeling that a piece of fiction is actually, to an unspecified degree, a piece of non-fiction, paradoxically without the facts having to completely match. This 'feeling' is necessarily based on a 'match of authenticity' between the narrative and the audience's expectations regarding this narrative. This is especially ironic because for many writers of fiction (if we are to believe their public statements), a narrative's relevance does not depend on its status as either fictional or nonfictional.

I do not think this is a coincidence. Many immigrant fictions are, among many other things, narratives about what it means to be / become ‘American';

\footnotetext{
4 As Winfried Fluck has argued together with Welf Werner (2003), one reason why the USA are traditionally less troubled about sharp socio-economic differences is that differences as a result of gender or race are unfair because they are genotypic (one cannot be blamed for one's gender or race), while class differences can be overcome (one can be blamed for "laziness"). Fluck (2002) has also argued that in the course of the second half of the twentieth century, economic matters and class membership have receded behind the focus on an "expressive individualism."
} 
they participate (whether they want to or not) in the negotiation of a national identity. In other words, they do the work of 'myth', in particular the myth that the USA are a nation of immigrants (which is, of course, factually correct, but factuality is not the primary aspect of myth). If we now look at the content of Hochschild's deep story, we find that, ironically, it is also about what it means to be American, only that it focuses on another aspect of that identity and myth: hard work, self-sufficiency, and initiative pay off; if not for you, then for your children. Crucially, the initial playing field is level for all players. Note that both of these narratives are 1) about identity, but over and beyond the identity politics of 'smaller' (i.e. non-national) aggregate 'cultural groups', and 2) about socioeconomics. Not to be misunderstood: many immigrant fictions also are about hard work, self-sufficiency, and initiative. However, as I have argued, the latter aspect is often overlooked in the reception of immigrant fictions, which are usually taken to be about cultural identity, and only that. Prominent novelistic subjects of this kind of 'forgetful' reception are, for example, China Boy by Gus Lee (1994), Lahiri's fictions, The Joy Luck Club by Amy Tan (1989), or Typical American by Gish Jen (1991).

In light of all this, it becomes easier to explain, among other things, why Donald Trump appeals to many US-Americans over and beyond older, rural, white, male Republicans (what some commentators call the white identity of mainstream American) despite the fact that some of his comments could be expected to alienate large voter groups (women, second generation immigrants, etc.). Conventional 'identity logic' simply does not fully explain his success. Rather, he finds favor across a diverse spectrum of the US-American public among those disappointed with the national mythic promises of the American Dream - just like Barack Obama, by the way. Since few of the participants in this myth-inflected discourse (be they politicians or writers of fiction) have questioned the myth per se (other than, for example, Bernie Sanders), it is almost 'convenient' (for lack of a better word) that the socioeconomic paradoxes and problems can be 'hidden' behind debates about cultural / national identity.

It also becomes easier to explain why it is pointless to counter a deep story or a narrative that is perceived as authentic simply with facts and factuality: authenticity circumvents any binary concept of fact and non-fact, fictionality and nonfictionality - in some contexts, appearing authentic or truthful is much more important than adhering to facts. ${ }^{5}$ Moreover, it explains the eerie structur-

5 Ironically, a close look at the migration narratives that are so often upheld as textual strongholds and paragons of authenticity and cultural identity shows that, nine times out of ten, they cleverly undermine such reductive appropriation. Unfortunately, that irony is often lost. 
al resemblance between some rhetoric on the political 'left' and on the 'right'. The content of the message may differ, but the underlying logic is similar.

\section{Conclusions}

The playful conflation of fictionality and nonfictionality in immigrant fiction may appear harmless, but it is not. While it is most of the time used to rightly question the idea that there is one unambiguous, univocal narrative of (historical) events and that a narrative's relevance does not inevitably depend on its (non)fictional status, the same strategy can also be used for devastating effects in other discourses and fields, making it possible to circumvent facts and factuality and (re)creating myths that may command significant parts of the political constituency. 'Felt truth' and authenticity may be highly amorphous, ephemeral, and unstable, but they nonetheless constitute an important element of the production and reception of certain narratives und undermine 'simple' binaries. This needs to be taken into account when analyzing what and how cultural narratives, myths, and deep stories take hold and are perpetuated, and to what effect. Similarly, 'forgetful' critical reception and 'illegitimate authentication' may merely appear to be perhaps unavoidable but negligible professional deformations, when in fact they are, I believe, tell-tale signs of wider discursive practices that have very real and, literally, powerful consequences. ${ }^{6}$ Lastly, I would like to point out just how ironic and mind-bogglingly paradoxical it is that we can diagnose a return of and penchant for the 'real', but that it comes in the form of a concept - authenticity - that inherently obviates the very possibility of determining that 'real'. It would almost be funny, if the consequences were not so dire.

\footnotetext{
6 They also are, by the way, context- and domain-sensitive. In other words, there may be similarities and parallels between populism, identitarian movements, and debates about 'postfactuality' in the USA and Europe, but we should not conflate them. On the contrary, there are important differences, not least of all in the specific cultural narratives, myths, and deep stories that 'work' in one context, but not another. Ignoring these differences will lead to gross misunderstandings and even dangerous simplifications.
} 


\section{Bibliography}

Alvarez, Julia. ;Yo!. New York: Plume, 1997.

Alvarez, Julia. How the García Girls Lost Their Accents. New York: Plume, 1991.

Anthias, Floya. "New Hybridities, Old Concepts: The Limits of 'Culture”". Ethnic and Racial Studies 24.4 (2001): 619-641.

Appiah, Kwame Anthony. The Ethics of Identity. Princeton: Princeton University Press, 2005.

Cantiello, Jessica Wells. “'That Story About the Gun': Pseudo-Memory in Julia Alvarez's Autobiographical Novels”. MELUS 36.1 (2011): 83-108.

Cutter, Martha J. "The Novel in a Changing America: Multiculturalism and Other Issues (1970Present)". A Companion to The American Novel. Ed. Alfred Bendixen. Chichester: WileyBlackwell, 2012. 109-126.

Dix, Andrew, Brian Jarvis, and Paul Jenner (eds.). The Contemporary American Novel in Context. New York: Continuum, 2011.

Fischer-Lichte, Erika, and Isabel Pflug (eds.). Inszenierung von Authentizität. Tübingen: Francke, 2000.

Fluck, Winfried, and Welf Werner (eds.). Wie viel Ungleichheit verträgt die Demokratie? Armut und Reichtum in den USA. Frankfurt a. M.: Campus, 2003.

Fluck, Winfried. "The Humanities in the Age of Expressive Individualism and Cultural Radicalism". The Future of American Studies. Ed. Donald E. Pease and Robyn Wiegman. Durham: Duke University Press, 2002. 211-230.

Foner, Nancy. In a New Land: A Comparative View of Immigration. New York: New York University Press, 2005.

Funk, Wolfgang, and Lucia Krämer (eds.). Fiktionen von Wirklichkeit: Authentizität zwischen Materialität und Konstruktion. Bielefeld: Transcript, 2011.

Haselstein, Ulla, Andrew Gross, and Maryann Snyder-Körber (eds.). The Pathos of Authenticity. Heidelberg: Universitätsverlag Winter, 2010.

Hochschild, Arlie Russell. Strangers in Their Own Land. New York/London: The New Press, 2016.

Huntington, Samuel. Who Are We? London: Free Press, 2004.

Isenberg, Nancy. White Trash. The 400-Year Untold History of Class in America. London: Atlantic Books, 2016.

Jen, Gish. Typical American. New York: Vintage, 1991.

Kuttner, Robert. "Steve Bannon, Unrepentant”. The American Prospect, 16 August 2017.

Lahiri, Jhumpa. The Interpreter of Maladies. Boston: Houghton Mifflin, 1999.

Lahiri, Jhumpa. The Namesake. London: Harper Perennial, 2003.

Lahiri, Jhumpa. Unaccustomed Earth. New York: Knopf, 2008.

Le, Nam. The Boat. New York: Knopf, 2008.

Lee, A. Robert. "Multiethnicities: Latino/a and Asian American Fiction”. American Fiction After 1945. Ed. John N. Duvall. Cambridge: Cambridge University Press, 2012. 114-128.

Lee, Gus. China Boy. New York: Plume, 1994.

Ludwig, Samuel. "Thin Pluralism: Some Observations on American Multiculturalism”. Theories of American Culture - Theories of American Studies. Ed. Winfried Fluck and Thomas Claviez. REAL: Yearbook of Research in English and American Literature 19 (2003): 225-245. 
Michaels, Walter Benn. "Model Minorities and the Minority Model - the Neoliberal Novel". The Cambridge History of the American Novel. Ed. Leonard Cassuto, Clare Virginia Eby, and Benjamin Reiss. Cambridge: Cambridge University Press, 2011. 1016-1030.

Michaels, Walter Benn. The Trouble with Diversity. New York: Holt, 2006.

Newman, George, and Rosanna Smith. "Kinds of Authenticity". Philosophy Compass 11/10 (2016): 609-618.

Schillinger, Liesl. “American Children”. Rev. of Unaccustomed Earth, by Jhumpa Lahiri. New York Times, 6 April 2008.

Smith, Sidonie, and Julia Watson. "The Trouble with Autobiography: Cautionary Notes for Narrative Theorists". A Companion to Narrative Theory. Ed. James Phelan and Peter J. Rabinowitz. Malden: Blackwell, 2008. 356-371.

Sollors, Werner. "Ethnic Modernism". The Cambridge History of American Literature. Vol. Six: Prose Writing, 1910-1950. Ed. Sacvan Bercovitch. Cambridge: Cambridge University Press, 2002. 355-556.

Sollors, Werner. Beyond Ethnicity: Consent and Descent in American Culture. New York: Oxford University Press, 1986.

Tan, Amy. The Joy Luck Club. New York: Ivy Books, 1989.

Taylor, Charles. The Ethics of Authenticity. Cambridge, MA: Harvard University Press, 1991.

Trilling, Lionel. Sincerity and Authenticity. Cambridge, MA: Harvard University Press, 1972. 